\title{
PERILAKU SADAR LINGKUNGAN PEMUKIM BANTARAN SUNGAI JELAI, KABUPATEN SUKAMARA
}

\section{ENVIRONMENTAL CONSCIOUS BEHAVIOR OF SETTLER JELAI RIVER BANKS, SUKAMARA DISTRICT}

\author{
Nova Purwanto \\ 'Badan Penatausahaan Keuangan dan Aset Daerah Kabupaten Sukamara; Provinsi Kalimantan Tengah; \\ nova.purwanto74@gmail.com
}

Info Artikel:

- Artikel Masuk: 13/03/18

- Artikel diterima: 24/05/18

- Tersedia Online: 28/02/18

\begin{abstract}
ABSTRAK
Terbentuknya wilayah pertumbuhan baru sebagai hasil perkembangan desa telah memicu pertumbuhan penduduk yang dapat membawa ekses negatif terhadap lingkungan dan keberlanjutannya. Untuk menciptakan kondisi lingkungan yang berkesinambungan harus menyelaraskan tiga komponen pokok yaitu lingkungan, ekonomi, dan sosial. Peran masyarakat menjadi penting, mengingat melalui perilaku sehari-hari dengan persepsi lingkungan yang dimiliki secara langsung atau tidak langsung dapat membuat lingkungan menjadi lebih baik atau lebih buruk. Tujuan penelitian ini adalah untuk mengetahui pengetahuan konseptual tentang indikator perilaku masyarakat terhadap kesadaran dan keberlanjutan lingkungan. Metode penelitian yang dipakai adalah survey eksplanatori. Pengambilan sampel dengan teknik simple random sampling. Teknik analisis menggunakan statistik deskriptif, dan analisis part least square. Hasil penelitian menunjukkan bahwa faktor yang berpengaruh terhadap persepsi dan perilaku sadar lingkungan adalah pendidikan dan pendapatan. Sedangkan indikator umur dan lama waktu kerja tidak berpengaruh terhadap persepsi dan perilaku sadar lingkungan. Keterbatasan biaya, ketersediaan sarana dan tempat menjadi kendala utama dalam mewujudkan perilaku sadar lingkungan. perilaku sadar lingkungan masyarakat dipengaruhi oleh cara pandangnya terhadap lingkungan, sehingga untuk keberlanjutan lingkungan, masyarakat perlu menerapkan prinsip-prinsip etika lingkungan dalam kehidupan sehari-hari. Kata Kunci: Karakteristik Sosial Ekonomi; Persepsi Lingkungan; Perilaku Sadar Lingkungan
\end{abstract}

\section{ABSTRACT}

The formation of new growth areas as a result of village development has triggered population growth that can bring negative excesses to the environment and its sustainability. To create sustainable environmental conditions must harmonize the three main components of environmental, economic, and social. The role of the community becomes important, considering that through daily behavior with the perception of the environment that is owned directly or indirectly can make the environment better or worse. The purpose of this research is to know conceptual knowledge about society behavior indicator to environmental awareness and sustainability. The research method used is explanatory survey. Sampling with simple random sampling technique. The analytical technique used descriptive statistics, and part least square analysis. The results showed that the indicator of education and income influenced, while age and duration of work did not affect the perception and behavior of conscious environment. Limitations of costs, the availability of facilities and places become the main obstacle in realizing environmentally conscious behavior. the environmental conscious behavior of the community is influenced by its perspective on the environment, so for environmental sustainability, society needs to apply the principles of environmental ethics in everyday life.

Keyword: Socio-Economic Characteristics; Environmental Perception; Environmental Conscious Behavior 


\section{PENDAHULUAN}

Perkembangan dan pertambahan penduduk kota terus mengalami peningkatan serta meningkatkan kebutuhan dalam aspek ekonomi, sosial, budaya, politik, teknologi dan ruang perkotaan yang lebih besar dan ekses negatif terhadap kualitas lingkungan hidup (Zulkifli, 2015). Diantara permasalahan lingkungan adalah pemanasan global sebagai dampak dari aktifitas masyarakat dalam konsumsi energi utamanya yang berbahan bakar fosil. Permasalahan lainnya adalah kekurangan air bersih dan rendahnya akses terhadap sanitasi yang layak. Rendahnya kepedulian masyarakat terhadap pengelolaan air limbah rumah tangga dan degradasi Daerah Aliran Sungai (DAS) di daerah hulu, menurunnya debit sumber air, dan tingginya laju sedimentasi pada tampungan air semakin menegaskan permasalahan ini. Sampah menjadi masalah berikutnya dimana Indonesia sudah masuk kategori darurat sampah. Plastik merupakan kontributor sampah terbesar selain makanan, dimana Indonesia menyumbang 200.000 ton plastik di laut (14,2 persen total sampah plastik dunia) dari empat sungai besar di Jawa dan Sumatera (Lebreton, 2017). Manusia tidak dapat dipisahkan dengan lingkungan. Hubungan interdependen manusia dengan lingkungan sangat rumit dan banyak variabel yang berperan ketika terjadi masalah lingkungan. Kerusakan lingkungan, menurut J. Baros dan J. M. Johnson (dalam Zulkifli, 2015), erat kaitannya dengan aktivitas manusia, antara lain kegiatan industri, pembangunan, transportasi, dan pertanian. Konsep yang sama dikemukakan oleh Munasinghe (dalam Zulkifli, 2015), bahwa interaksi manusia dan lingkungan tidak dapat dipisahkan dalam menciptakan pembangunan berkelanjutan, dimana interaksi tiga elemen utama yaitu lingkungan, ekonomi, dan sosial harus seimbang, tidak boleh satu melebihi yang lain.

Kelurahan Padang sebagai salah satu pusat kegiatan perdagangan di Sukamara, berada di bantaran Sungai Jelai. Dengan kepadatan penduduk, keragaman karakteristik sosial ekonomi yang dimiliki, keterbatasan wilayah untuk permukiman, dan aktifitas kurang peduli terhadap lingkungan sekitar telah menimbulkan lingkungan yang kumuh. Sebagian masyarakat masih memanfaatkan air sungai untuk kegiatan mandi, cuci, dan kakus (MCK) bahkan untuk masak dan minum serta menjadikan sungai sebagai tempat untuk pembuangan limbah rumah tangga. Perilaku tersebut menyebabkan penurunan kualitas lingkungan sungai dan terganggunya kesehatan masyarakat antara lain demam berdarah dan diare. Terganggunya lingkungan juga terlihat dari pendangkalan dan penyempitan sungai. Kawasan bantaran sungai menurut Undang-undang Nomor 26 Tahun 2007 dan Peraturan Pemerintah Nomor 26 Tahun 2008 telah ditetapkan sebagai kawasan terbuka hijau. Pada sisi lain Undang-undang Nomor 32 Tahun 2009 dan Peraturan Pemerintah Nomor 27 Tahun 2012 mengamanatkan pelibatan masyarakat dalam pengelolaan lingkungan hidup. Atas dasar itu perlu dilakukan penelitian mengenai keterkaitan karakteristik sosial ekonomi masyarakat terhadap persepsi dan perilaku sadar lingkungan yang dimilikinya. Bantaran sungai atau sempadan sungai adalah ruang antara tepi palung sungai dan kaki tanggul sebelah dalam yang terletak di kiri dan/atau kanan palung sungai (Peraturan Menteri PU No. 28/PRT/M/2015). Maryono (2015), sempadan sungai biasa disebut bantaran sungai meski terdapat sedikit perbedaan dimana area bantaran sungai merupakan area yang tepat berada di tepi sungai dan merupakan area yang tertutup oleh luapan air sungai saat banjir (flood plain), sehingga sempadan sungai adalah bantaran sungai ditambah lebar longsoran sungai, lebar bantaran ekologis dan lebar bantaran keamananan.

Permukiman bantaran sungai dalam perkembanganya menghadapi berbagai masalah lingkungan akibat dilupakannya aspek lingkungan dan mengutamakan aspek ekonomi dalam kegiatan bermukim. Untuk itu perlu didorong upaya keseimbangan lingkungan melalui permukiman ramah lingkungan. Indikator permukiman ramah lingkungan menurut Joga (dalam Triyuly, 2010) mencakup pemilihan lokasi yang tepat, optimalisasi lahan secara berimbang, penerapan zero water treatmen, pengendalian pencemaran udara, penerapan zero waste, dan green building code. Beberapa aspek yang digunakan untuk melihat karakteristik sosial ekonomi adalah umur, pekerjaan, pendapatan, dan pendidikan formal. Brim (dalam Gulam, 2011), proses tersosialisasinya seseorang di umur tertentu karena adanya interaksi dari lingkungan sekitar dan etika maupun kepercayaan yang berlaku di suatu sistem sosial. Pendidikan formal dapat mempengaruhi sikap dan perilaku melalui nilai, budi pekerti dan pemahaman terhadap suatu permasalahan yang dibangun secara bertahap pada diri seseorang. Jenis pekerjaan yang dimiliki seseorang 
dan lama waktu bekerja akan mempengaruhi pola pikir dan tingkah laku terhadap lingkungannya. Hutomo (dalam Gulam, 2011), pada masyarakat miskin hanya memiliki dua sumber pendapatan, melalui gaji/surplus usaha informal untuk kebutuhan pokoknya saja.

\subsection{Persepsi Kesadaran Lingkungan}

Persepsi dalam arti sempit adalah penglihatan, bagaimana cara seseorang melihat sesuatu, sedang dalam arti luas adalah pandangan atau pengertian yaitu bagaimana seseorang memandang atau mengartikan sesuatu (Leavitt, 1978). Sementara Thoha (2001) mendefinisikan persepsi adalah proses kognitif yang dialami oleh setiap orang dalam memahami informasi tentang lingkungannya, baik melalui penglihatan, pendengaran, penghayatan, perasaan maupun penciuman. Persepsi kesadaran lingkungan mencakup indikator sanitasi, pemanfaatan air, pengelolaan sampah dan penghematan energi, bahan bakar dan emisi karbon. Persepsi dinyatakan dalam indeks dengan tiga kategori yaitu tinggi, sedang, dan rendah.

\subsection{Perilaku Sadar Lingkungan}

Terdapat tiga tradisi besar orientasi teori psikologi dalam menjelaskan dan memprediksi perilaku manusia. Pertama, perilaku disebabkan faktor dari dalam (deterministik). Kedua, perilaku disebabkan faktor lingkungan atau proses belajar. Ketiga perilaku disebabkan interaksi manusia-lingkungan. Teoriteori yang berorientasi deterministik lebih banyak digunakan untuk menjelaskan fenomena kognisi lingkungan. Dalam hal ini, teori yang digunakan adalah teori Gestalt. Menurut teori Gestalt, proses persepsi dan kognisi manusia lebih penting daripada mempelajari perilaku tampaknya (overt behaviour). Bagi Gestalt, perilaku manusia lebih disebabkan oleh proses-proses persepsi. Dalam kaitannya dengan psikologi lingkungan, maka persepsi lingkungan merupakan salah satu aplikasi dari teori Gestalt (Iskandar, 2012). Membicarakan perilaku manusia terkait lingkungan tidak bisa lepas dari etika lingkungan. Keraf (2010), etika lingkungan merupakan cara pandang manusia dengan manusia, hubungan antara manusia dengan alam, serta perilaku yang bersumber dari cara pandang ini. Tiga teori etika lingkungan yaitu antroposentrisme (shalllow enviromental ethics), biosentrisme (intermediate environmental ethics), dan ekosentrisme (deep environmental ethics). Latar belakang kondisi saat ini dalam hal polusi, populasi yang berlebih, krisis lingkungan secara global, dan isu keberlanjutan bumi, adalah hal yang mendasari teori ekosentrisme lebih berkembang. Atas dasar teori biosentrisme dan ekosentrisme maka dikembangkan prinsip etika lingkungan yaitu sikap hormat terhadap alam, tanggung jawab, solidaritas kosmis, kasih sayang dan kepedulian terhadap alam, tidak merugikan alam, hidup sederhana dan selaras dengan alam, keadilan, demokrasi, dan integritas moral. Penelitian ini mengadopsi Indeks Perilaku Peduli Lingkungan yang dilaksanakan BPS (KLH, 2013), dengan cakupan indikator perilaku sadar lingkungan meliputi perilaku sanitasi, perilaku pemanfaatan air, perilaku pengelolaan sampah, dan perilaku hemat energi, bahan bakar dan emisi karbon. Perilaku dinyatakan dalam indeks dengan tiga kategori yaitu tinggi, sedang, dan rendah. Untuk mencari hubungan antar variabel yaitu karakteristik sosial ekonomi, persepsi lingkungan, dan perilaku sadar lingkungan pemukim menggunakan pendekatan Structural Equation Modelling-Partial Least Square (SEM-PLS). Dengan alat analisis ini dapat melakukan permodelan persamaan struktural dengan ukuran sampel relatif kecil dan tidak membutuhkan asumsi normal multivariate (Jaya, 2008).

Permodelan PLS terdiri tiga komponen, yaitu struktural, pengukuran dan pembobotan. Dapat dikatakan bahwa variabel laten karakteristik sosial ekonomi pemukim (KARAKTERISTIK) ditentukan oleh indikator umur, pendidikan, pekerjaan, dan pendapatan pemukim. Variabel laten persepsi pemukim (PERSEPSI) menentukan indikator persepsi tentang pengelolaan sampah, pemanfaatan air, pemanfaatan energi, dan sanitasi. Variabel laten perilaku sadar lingkungan pemukim (PERILAKU) akan menentukan indikator perilaku tentang pengelolaan sampah, pemanfaatan air, pemanfaatan energi, dan sanitasi. Secara struktural, variabel laten KARAKTERISTIK akan mempengaruhi variabel laten PERSEPSI, selanjutnya variabel laten PERSEPSI akan mempengaruhi variabel laten PERILAKU. Ilustrasi model diagram jalur sebagaimana Gambar. 1. 


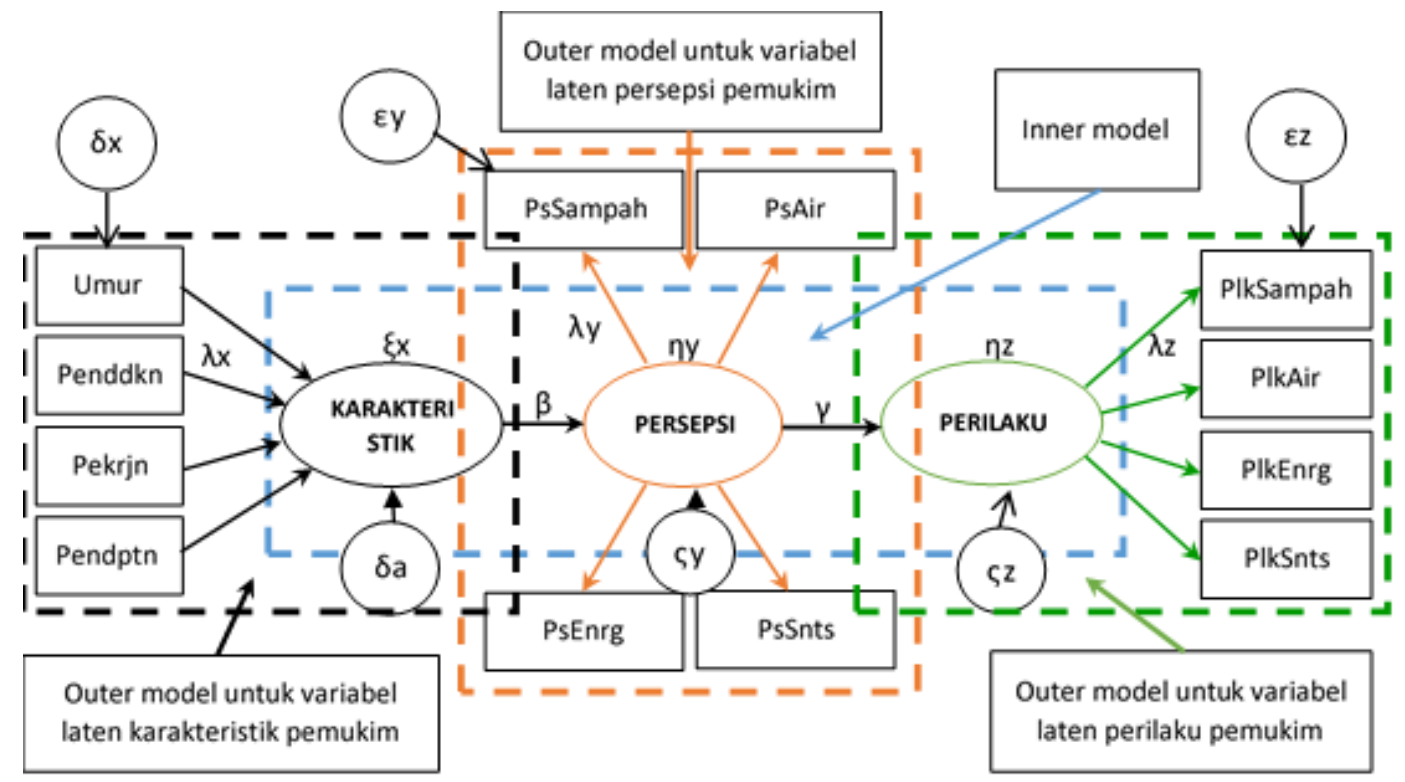

Gambar 1. Diagram Model Jalur Hubungan Karakteristik, Persepsi, Dan Perilaku Sadar Lingkungan Pemukim (Interpretasi penulis, 2017)

Diagram jalur di atas dikonversi dalam persamaan menjadi (Jaya, 2008):

a. Outer model

Untuk variabel latent eksogen KARAKTERISTIK (formatif)

$$
\xi \mathrm{x}=\lambda \mathrm{x}_{1} \mathrm{X}_{1}+\lambda \mathrm{x}_{2} \mathrm{X}_{2}+\lambda \mathrm{x}_{3} \mathrm{X}_{3}+\lambda \mathrm{x}_{4} \mathrm{X}_{4}+\delta \mathrm{a}
$$

Untuk variabel latent endogen PERSEPSI (reflektif)

$$
\mathrm{y} 1-4=\lambda \mathrm{y} 1-4 \eta \mathrm{y}+\varepsilon \mathrm{y} 1-4
$$

Untuk variabel latent endogen PERILAKU (reflektif)

$$
z 1-4=\lambda z 1-4 \eta z+\varepsilon z 1-4
$$

b. Inner model

$$
\begin{aligned}
& \eta y=\beta \xi x+\varsigma y \\
& \eta z=\gamma 1 \eta z+\varsigma z
\end{aligned}
$$

c. Weight relation

$$
\begin{aligned}
& \xi \mathrm{b}=\Sigma k b w k b \times k b \\
& \eta \mathrm{i}=\Sigma k i \text { wki } y k i
\end{aligned}
$$

dimana:

$\xi=\mathrm{Ksi}$, variabel latent eksogen (KARAKTERISTIK)

$\eta y z=$ Eta, variabel laten endogen (PERSEPSI dan PERILAKU)

$\lambda x=$ Lamnda (kecil), loading factor variabel latent eksogen (KARAKTERISTIK)

$\lambda y z=$ Lamnda (kecil), loading factor variabel latent endogen (PERSEPSI dan PERILAKU

$\beta=$ Beta (kecil), koefisien pengaruh variabel endogen (PERSEPSI) terhadap variabel endogen (PERILAKU)

$\gamma=$ Gamma (kecil), koefisien pengaruh variabel eksogen (KARAKTERISTIK) terhadap variabel endogen (PERSEPSI)

$\varsigma=$ Zeta (kecil), galat model

$\delta=$ Delta (kecil), galat pengukuran pada variabel manifest untuk variabel laten eksogen

$\varepsilon=$ Epsilon (kecil), galat pengukuran pada variabel manifest untuk variabel latent endogen 
Hipotesis statistik untuk outer model adalah:

$\mathrm{Ho}: \lambda \mathrm{i}=\mathrm{o}$ lawan

$\mathrm{H} 1: \lambda \mathrm{i} \neq 0$,

Hipotesis statistik untuk inner model: pengaruh variabel laten eksogen yaitu variabel laten KARAKTERISTIK terhadap variabel endogen yaitu variabel laten PERSEPSI atau pengaruh tidak langsung variabel laten KARAKTERISTIK terhadap variabel laten PERILAKU adalah

Ho $: \gamma \mathrm{i}=\mathrm{o}$ lawan

$\mathrm{H} 1: \gamma \mathrm{i} \neq 0$,

Hipotesis statistik untuk inner model: pengaruh variabel laten endogen PERSEPSI terhadap variabel laten endogen PERILAKU adalah

$\mathrm{Ho}: \beta \mathrm{i}=\mathrm{o}$ lawan

$\mathrm{H} 1: \beta \mathrm{i} \neq 0$

\section{DATA DAN METODE}

Penelitian ini menggunakan metode kuantitatif yaitu survey eksplanatori untuk menyelidiki nilainilai dari dua atau lebih variabel yang berkorelasi dan menguji atau menentukan hubungan yang ada diantara mereka dalam lingkungan tertentu. Untuk mengetahui indeks persepsi dan perilaku sadar lingkungan menggunakan analisis frekuensi, sedangkan analisis part least square-structural equation modeling (PLS-SEM) untuk mengetahui hubungan antar variabel. Teknik pengambilan data dilakukan dengan cara penyebaran kuesioner, wawancara, dan observasi untuk mendapatkan data primer. Data sekunder diperoleh dari pihak lain, dengan meneliti dokumen-dokumen dari berbagai instansi pemerintah dan penelitian-penelitian terdahulu yang relevan.

Pengukuran indeks persepsi dan perilaku sadar lingkungan menggunakan populasi rumah tangga di Kelurahan Padang yang bermukim bantaran Sungai Jelai. Metode pengambilan sampel menggunakan teknik sampling acak sederhana (simple random sampling), dimana semua elemen dalam populasi yang didefinisikan mempunyai kesempatan yang sama, bebas dan seimbang untuk dipilih menjadi sampel.

\subsection{GAMBARAN FISIK LINGKUNGAN DAN KARAKTERISTIK SOSIAL EKONOMI PEMUKIM BANTARAN SUNGAI JELAI}

Kelurahan Padang adalah salah satu kelurahan di Kecamatan Sukamara, Kabupaten Sukamara, Propinsi Kalimantan Tengah. Secara astronomis terletak pada $2^{\circ} 44^{\prime} 02^{\prime \prime}$ LS, $111^{\circ} 10^{\prime} 17^{\prime \prime}$ BT dan secara geografis berada di daerah tepi/sekitar hutan. Total luas wilayah Kelurahan Padang adalah 156 km2, Kelurahan Padang berada pada ketinggian sekitar 5 - 15 meter di atas permukaan laut dengan tingkat kemiringan $0-8$ derajat. Permukiman bantaran Sungai Jelai memiliki lokasi strategis karena mudah diakses dan berdekatan dengan pusat perdagangan. Jalan lingkungan memadai dengan ukuran lebar $4 \mathrm{~m}$ sepanjang 1,9 km dan jalan titian/gang dengan ukuran lebar 0,8-1 m dan panjang $20-60 \mathrm{~m}$. Jaringan drainase berfungsi normal. Jaringan air bersih dari PDAM telah memenuhi sebagian warga. Sistem sanitasi belum sepenuhnya menerapkan pemilahan grey water dan black water. Sarana persampahan telah disediakan di titik-titik tertentu tapi ukurannya kurang memadai, sebagian telah rusak dan sampah belum dipilah. Jaringan listrik, telekomunikasi, pendidikan, kesehatan, peribadatan, perdagangan sudah memadai, Sarana ruang terbuka tersedia di dekat Pasar Inpres. 


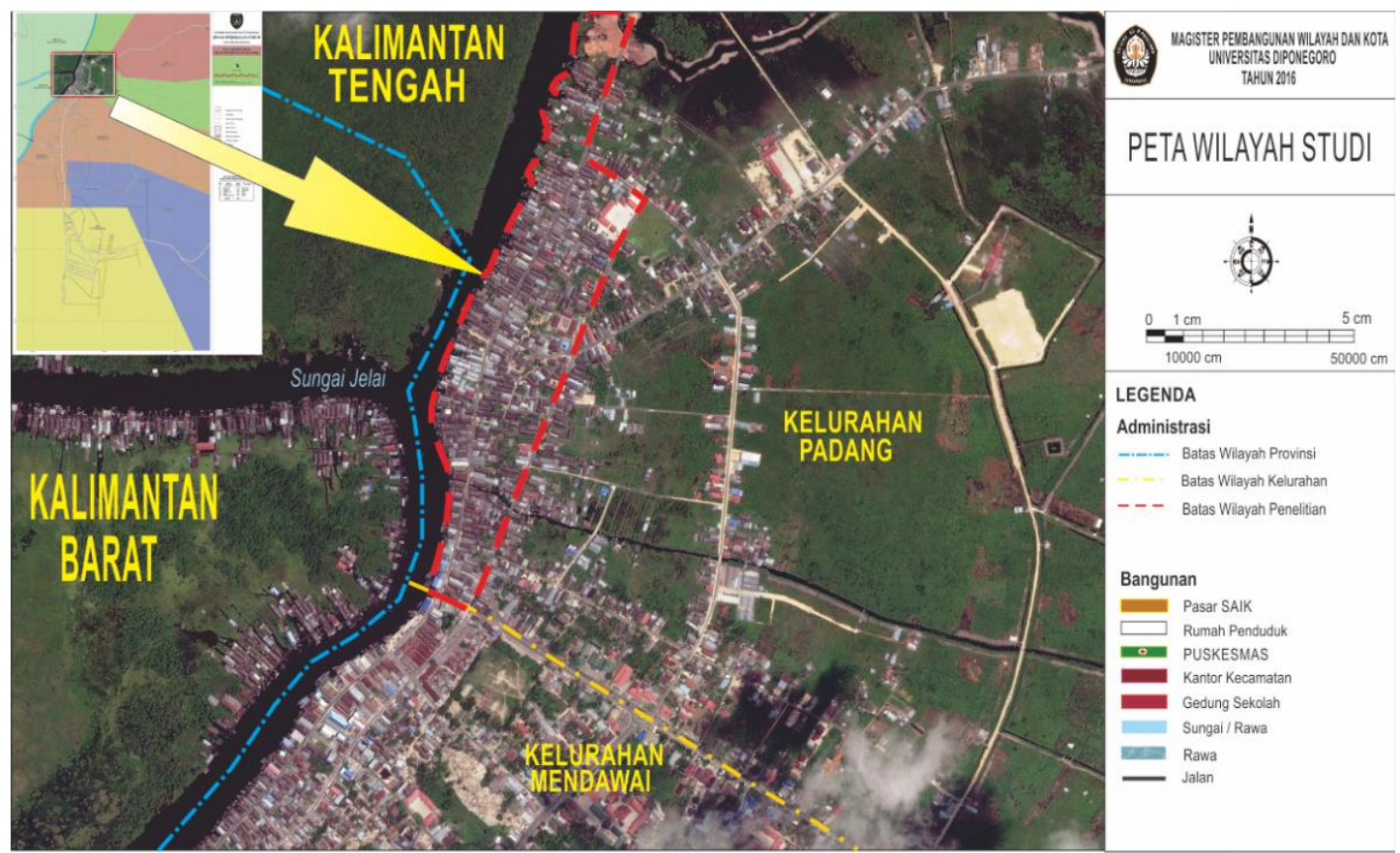

Gambar 2. Peta Lokasi Pemukim Bantaran Sungai Jelai Di Kelurahan Padang

(Foto Udara Kecamatan Sukamara Tahun 2013, diolah)

Karakteristik sosial ekonomi pemukim bantaran Sungai Jelai didominasi keluarga dengan jumlah anggota keluarga 3 orang sebanyak 28 persen. Kelompok umur dominan pada usia $35-49$ tahun sebanyak 65 persen. Untuk pendidikan, mayoritas pemukim menamatkan pendidikan Sekolah Dasar (SD) sebanyak 31 persen, diikuti tamatan Sekolah Menengah Atas (SMA) sebanyak 26 persen. Lapangan pekerjaan pemukim bervariasi dengan dominansi pada sektor wiraswasta sebanyak 25 persen dengan pendapatan dominan Rp. 3.000.000,- s.d. Rp. 3.999.900,-, diikuti petani/pekebun dan perdagangan masing-masing sebanyak 15 dan 13 persen dengan pendapatan dominan masing-masing Rp. 2.000.000,- s.d. Rp. 2.999.900,- dan Rp. 3.000.000,- s.d. Rp. 3.999.900,-. Lama waktu bekerja dalam sehari berkisar antara 5 10 jam. Pendapatan dominan pemukim berada pada kisaran Rp. 2.000.000,- s.d. Rp. 2.999.900,- dengan pendidikan SD dan SMP.

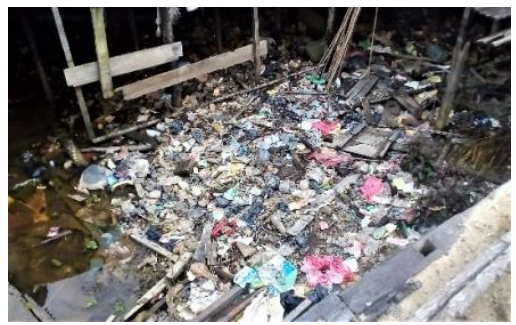

(a)

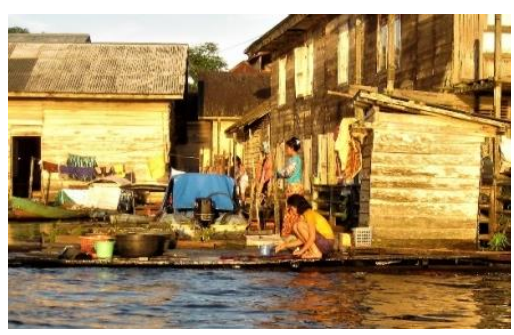

(c)

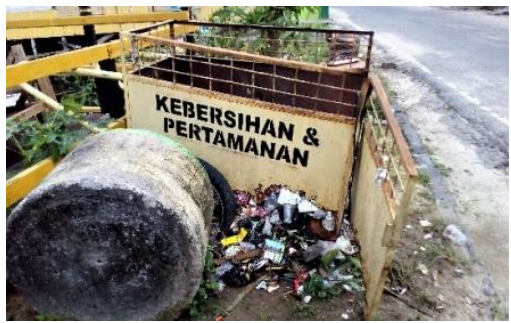

(b)

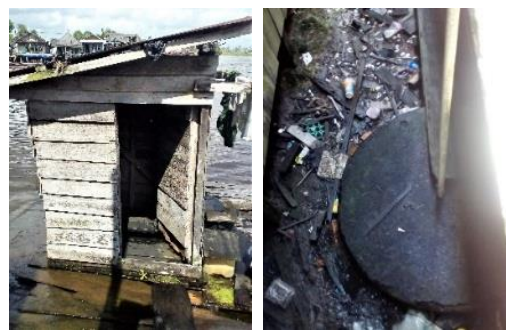

(d)

Gambar 3. Kondisi Lingkungan Fisik Permukiman Bantaran Sungai Jelai (Dokumentasi, 2017) 
Keterangan:

(a) Sungai sebagai tempat pembuangan sampah.

(b)Tempat sampah tidak layak dan memadai.

(c) Sungai sebagai tempat melangsungkan kegiatan MCK.

(d)Jamban apung cemplung dan septik tank pemukim.

\section{HASIL DAN PEMBAHASAN}

\subsection{Persepsi Pemukim dan Indeks Perilaku Peduli Lingkungan}

Dari hasil analisis frekuensi terhadap variabel persepsi, indikator sanitasi, pengelolaan sampah, pemanfaatn air, dan penghematan energi, bahan bakar dan emisi karbon diperoleh nilai rerata indeks masing-masing adalah 73,67 persen; 72,75 persen; 78,33 persen; dan 65,87 persen. Dari nilai rerata masingmasing indikator tersebut kemudian digabung untuk mendapatkan indeks persepsi lingkungan menghasilkan nilai indeks 72,65 persen dengan kategori tinggi. Pada penilaian kesadaran lingkungan pada indikator sanitasi, pemanfaatan air, pengelolaan sampah, dan penghematan energi, bahan bakar dan emisi karbon diperoleh nilai rerata indeks masing-masing adalah 25 persen; 48,2 persen; 20,75 persen; dan 51,37 persen. Dari nilai rerata indeks masing-masing indikator perilaku tersebut kemudian digabung untuk mendapatkan indeks perilaku sadar lingkungan menghasilkan nilai indeks 36,33 persen dengan kategori sedang.

\subsection{Analisis Structural Equation Modelling-Partial Least Square (SEM-PLS)}

Dari hasil uji hipotesis dengan teknik Structural Equation Modelling-Partial Least Square (SEM-PLS) didapatkan hasil sebagaimana dalam tabel 1.

Tabel 1. Hasil Uji Hipotesis (Hasil Olah Data, 2017)

\begin{tabular}{|c|l|c|c|c|c|}
\hline \multicolumn{6}{|l|}{ Hasil analisis pengaruh langsung variabel laten } \\
\hline Hipotesis & \multicolumn{1}{|c|}{ Hubungan antar variabel } & $\begin{array}{c}\text { Koefisien } \\
\text { Jalur }\end{array}$ & T-stat & $\begin{array}{c}\text { p- } \\
\text { value }\end{array}$ & Hasil \\
\hline $\mathrm{H}_{1}$ & Karakteristik $\rightarrow$ Persepsi & 0,831 & 31,218 & 0,000 & Signifikan \\
\hline $\mathrm{H}_{2}$ & Persepsi $\rightarrow$ Perilaku & 0,588 & 9,526 & 0,000 & Signifikan \\
\hline Hasil analisis pengaruh tidak langsung variabel laten \\
\hline $\mathrm{H}_{3}$ & Karakteristik $\rightarrow$ Persepsi $\rightarrow$ Perilaku & 0,488 & 7,889 & 0,000 & Signifikan \\
\hline
\end{tabular}

Tabel 1 di atas, menunjukkan bahwa: (1) cukup bukti secara empiris untuk menerima hipotesis ( $\mathrm{H} 1)$ bahwa Karakteristik berpengaruh signifikan terhadap Persepsi, (2) cukup bukti secara empiris untuk menerima hipotesis $\left(\mathrm{H}_{2}\right)$ bahwa Persepsi berpengaruh signifikan terhadap Perilaku, dan (3) cukup bukti secara empiris untuk menerima hipotesis $\left(\mathrm{H}_{3}\right)$ bahwa Karakteristik secara tidak langsung berpengaruh signifikan terhadap Perilaku. Beberapa aspek fisik lingkungan masih perlu mendapat perhatian antara lain sarana air bersih untuk pemukim meskipun telah terpenuhi baik oleh PDAM maupun dari penyedia jasa air isi ulang dan air dalam kemasan namun masih tingginya konsumsi terhadap air isi ulang dan air dalam kemasan akan meningkatkan porsi belanja rumah tangga untuk air bersih mengingat harganya yang tidak murah. Pada jaringan air limbah, sebagian besar masyarakat masih menggunakan sarana MCK umum/bersama dan TPA tinja ke sungai yang dapat mencemari air tanah dan sungai serta menyebabkan penyakit. Alasan dari buruknya sarana sanitasi ini adalah ketersediaan tempat yang tidak mencukupi akibat padatnya penduduk dan mahalnya biaya pengadaan sarana sanitasi yang memenuhi standar. Kondisi ini dapat diselesaikan dengan mekanisme bantuan pendanaan dari luar negeri seperti di alami oleh pemukim bantaran Sungai Musi, atau bisa juga dengan menggunakan modifikasi septik tank terapung komunal oleh pemukim bantaran Sungai Kapuas, atau dengan mekanisme pembiayaan syariah "kredit jamban" seperti yang dilakukan oleh warga Desa Leuwibatu, Kecamatan Rumpin, Kabupaten Bogor.

Jaringan persampahan juga perlu mendapatkan perhatian serius karena kondisi yang buruk akibat interaksi antara sarana persampahan yang tidak memadai, dan masyarakat. Masyarakat beranggapan 
bahwa membuang sampah di sembarang tempat atau sungai tidak masalah, mereka beranggapan bahwa sampah itu akan hilang dengan sendirinya pada saat hujan atau hanyut terbawa arus sungai. Banyaknya masyarakat yang sangat jarang/tidak melakukan pemilahan sampah akan membawa dampak pada beratnya sistem pengolahan sampah akhir. Dampak tersebut bisa diminimalisir melalui pengomposan, $3 \mathrm{R}$ (Reduce, Reuse, Recycle), konsumen hijau, sampah dijadikan bahan bakar dan mekanisme pembangunan bersih (Sudarman, 2010). Dari hasil analisis partial least square, indikator umur dan pekerjaan tidak mampu secara signifikan untuk menjelaskan variabel laten Karakteristik. Beni (2014), dalam penelitiannya menunjukkan bahwa kelompok umur 40 - 59 tahun tidak memiliki pengaruh terhadap perilaku pengelolaan sampah domestik. Pengaruh tidak nyata umur terhadap pemahaman lingkungan dalam hal ini sanitasi juga dilaporkan oleh Nugroho (1999). Menurut Erikson (1950), individu pada kelompok umur 35 - 55 tahun adalah fase bekerja dengan kreatif dan bermakna, dan karya yang memberikan sumbangan pada kebaikan masyarakat. Pendapat yang sama dikemukakan oleh Jones \& Dunlap (dalam Andromeda, 2009), bahwa salah satu faktor yang berpengaruh terhadap kepedulian lingkungan adalah umur, yaitu umur dewasa muda adalah kelompok umur yang paling peduli terhadap lingkungan dibandingkan kelompok umur yang lain. Penulis beranggapan bahwa kurang signifikannya indikator umur ini bisa dimaknai lain yaitu karena pengalaman yang diperoleh individu pemukim selama hidup yang dilaluinya baik di dalam atau diluar keluarga tersebut tidak cukup mendukung ke arah kesadaran lingkungan.

Indikator pendidikan dan pendapatan berpengaruh terhadap persepsi lingkungan. Pembentukan nilai, penanaman budi pekerti, pemahaman pada suatu permasalahan diajarkan melalui tahap dalam pendidikan formal. Melalui pemaparan tersebut dapat dipastikan bahwa tingkat pendidikan formal pemukim memiliki pengaruh yang jelas dalam sikap maupun perilaku. Pendapatan yang diperoleh masyarakat mempengaruhi kemampuan untuk kecukupan kebutuhan hidupnya. Perkembangan teknologi informasi yang cepat saat ini telah membuat perangkat elektronik berganti dengan cepat berikut dengan teknologi yang menyertainya, hal ini membawa konsekuensi harga-harga peralatan elektronik tersebut turun dan semakin terjangkau oleh masyarakat berpendapatan rendah. Semakin banyak masyarakat yang memiliki peralatan teknologi informasi sehingga masyarakat mudah untuk mengakses informasi, salah satunya tentang lingkungan. Peningkatan akses informasi tentang lingkungan tersebut berpengaruh terhadap meningkatnya pemahaman masyarakat terhadap nilai-nilai kesadaran lingkungan. Pada variabel laten Persepsi indikator yang menonjol adalah pemanfaatan air diikuti dengan pengelolaan sampah, selanjutnya pemahaman tentang penghematan energi, bahan bakar, dan emisi karbon serta yang terakhir adalah pemahaman tentang sanitasi. Jalaludin Rakhmat (dalam Nararya, 2017) mengemukakan bahwa persepsi dipengaruhi oleh faktor-faktor sebagai berikut: (1) faktor yang bersifat fungsional, diantaranya kebutuhan, pengalaman, motivasi, perhatian, emosi dan suasana hati; (2) faktor yang bersifat struktural diantaranya intensitas rangsangan, ukuran rangsangan, perubahan rangsangan dan pertentangan rangsangan; (3) faktor kultural atau kebudayaan yaitu norma-norma yang dianut oleh individu. Dari pernyataan ini jelas kiranya mengapa persepsi yang menonjol pada pemukim bantaran sungai adalah pemahaman tentang pemanfaatan air. Bahwa secara fungsional karena sangat dibutuhkan, secara struktural yaitu intensitas rangsangan dan ukuran rangsangan, dan secara kultural pemukim bantaran sungai sangat kental dengan budaya sungai dalam kesehariannya.

Untuk variabel laten perilaku menunjukkan bahwa indikator yang memiliki nilai tinggi adalah indikator pemanfaatan air, diikuti dengan sanitasi, selanjutnya penghematan energi, bahan bakar, dan emisi karbon, terakhir pengelolaan sampah. Dari hasil tersebut, terlihat bahwa pemukim masih memprioritaskan kebutuhan dasarnya yaitu kebutuhan akan air sehingga terwujud dalam perilakunya. Motif ekonomi melatarbelakangi setiap perilaku sadar lingkungan tersebut. Dari hasil survey, alasan yang digunakan oleh pemukim dalam penghematan air adalah alasan biaya, demikian juga mengapa masyarakat belum banyak memiliki sarana sanitasi yang sehat alasan yang terkuat adalah karena mahalnya biaya untuk membuat sarana sanitasi sehat. Pada indikator penghematan energi, bahan bakar dan emisi karbon pemukim melakukan penghematan juga lebih karena alasan biaya. Untuk indikator pengelolaan sampah, pemukim masih sangat jarang melakukan tata kelola sampah secara baik karena urusan sampah ini bagi sebagian pemukim secara ekonomi masih dipandang belum menguntungkan, selain ketiadaan fasilitas dan 
ketidaktahuan. Dalam konteks ini sesuai dengan pendapat Maslow (dalam Salmah, 2010), yang menyatakan bahwa manusia belum akan memenuhi kebutuhan hidupnya yang lebih tinggi sebelum kebutuhan dasarnya terpenuhi.

Hasil analisis menunjukkan bahwa nilai persepsi yang tinggi tidak serta merta diikuti dengan tingginya perilaku kesadaran lingkungan. Penulis berpendapat bahwa kondisi ini bisa dimungkinkan oleh kurang tersedianya sarana untuk menunjang aksi dalam mewujudkan perilaku sadar lingkungan. Dalam perspektif penelitian ini, ditunjukkan dalam skor yang diperoleh dalam variabel persepsi untuk indikator pengelolaan sampah dimana skor yang diperoleh memiliki kategori tinggi sedangkan pada nilai indeks perilaku peduli lingkungan untuk indikator pengelolaan sampah memperoleh nilai skor rendah. Responden beralasan bahwa perilakunya itu timbul karena tidak ada fasilitas. Selain fasilitas alasan lain adalah kegiatan sadar lingkungan (memilah sampah) dipandang tidak menguntungkan secara ekonomi. Dari beberapa penjelasan di atas, maka dapat dijelaskan hubungan model dari penelitian ini yaitu: indikator pendidikan dan pendapatan secara bersama-sama merefleksikan variabel laten karakteristik sosial ekonomi individu pemukim. Berdasarkan kemampuan pendidikan dan pendapatan yang dimiliki tersebut, pemukim menentukan prioritas indikator persepsi sesuai dengan prioritas kebutuhan hidupnya. Keterbatasan kemampuan penghasilan yang dimiliki baru sebatas untuk pemenuhan kebutuhan dasarnya, ditambah dengan kurangnya sarana yang tersedia, maka kemampuan untuk mengimplementasikan persepsi dalam perilaku sadar lingkungan juga tidak setinggi tingkat persepsinya. Dalam berperilaku sadar lingkungan pemukim masih menempatkan indikator yang ada sesuai prioritas dalam kebutuhan hidupnya seperti dalam hirarki kebutuhan Maslow. Pada akhirnya, dapat dinyatakan bahwa masalah perilaku sadar lingkungan masyarakat tidak terlepas dari etika lingkungan mengingat perilaku masyarakat bersumber dari cara pandangnya baik terhadap sesama manusia maupun terhadap lingkungan sekitar. Oleh karena itu demi keberlanjutan lingkungan, masyarakat perlu menerapkan prinsip etika lingkungan dalam berinteraksi dengan lingkungan, yang bersumber dari teori biosentrisme dan ekosentrisme yaitu: sikap hormat terhadap alam, sikap tanggung jawab, solidaritas kosmis, kasih sayang dan kepedulian terhadap alam, tidak merugikan alam, hidup sederhana dan selaras dengan alam, keadilan, demokrasi, dan integritas moral (Keraf, 2010).

\section{KESIMPULAN}

Berdasarkan hasil analisis dan pembahasan pada bab sebelumnya, didapatkan beberapa kesimpulan sebagai berikut : (1) indikator umur dan lama waktu kerja tidak memberikan pengaruh terhadap persepsi dan perilaku sadar lingkungan yang dimiliki oleh masyarakat bantaran sungai, sementara pendidikan dan pendapatan memberikan pengaruh signifikan, (2) keterbatasan biaya, ketersediaan sarana dan tempat menjadi kendala utama bagi perwujudan persepsi ke dalam perilaku sadar lingkungan masyarakat bantaran sungai, (3) perilaku sadar lingkungan masyarakat dipengaruhi oleh cara pandangnya terhadap lingkungan, sehingga untuk keberlanjutan lingkungan, masyarakat perlu menerapkan prinsipprinsip etika lingkungan dalam kehidupan sehari-hari. Penelitian ini memperkuat teori Keraf dalam perilaku manusia tidak terlepas dari etika lingkungan. Dalam hal ini etika lingkungan dalam cara pandang manusia memandang lingkungan dipengaruhi oleh karakteristik, dan kemudian berpengaruh pula kepada perilaku. Namun ada hal yang menarik dari studi ini bahwa usia tidak terkait dengan kesadaran menjada lingkungan, dan hal ini berbeda dengan studi-studi yang selama ini dilakukan misalnya oleh Erickson atau Jones dan Dunlap.

\section{PERNYATAN RESMI}

Terima kasih kepada seluruh pihak, khususnya Pusbindiklatren Bappenas yang telah memberi kesempatan dan dukungan pembiayaan selama menjalani masa tugas belajar. 


\section{REFERENSI}

Andromeda, M.F.K. 2009. Relevansi Status Sosial Ekonomi Terhadap Kepedulian Lingkungan Hidup dalam Konteks Indonesia sebagai Negara Berkembang (Studi Kasus Rukun Warga 11, Kelurahan Warakas, Tanjung Priok, Jakarta Utara). Skripsi Tidak diterbitkan. Fakultas IImu Sosial dan Ilmu Politik Universitas Indonesia.

Beni, Martinus Tulit dkk. 2014. Pengaruh Faktor-Faktor Sosial-Ekonomi Terhadap Perilaku Pengelolaan Sampah Domestik di Nusa Tenggara Timur. Jurnal Ilmu Lingkungan Vol. 12 Issue 2: 105-117 (2014). Program Studi Ilmu Lingkungan, Program Pasca Sarjana UNDIP. Semarang.

Erikson, H. Erik. 1950. Childhood and Society. American Association for the Advancement of Science. New York.

Gulam, Patih Megawanda. 2011. Faktor-Faktor yang Berhubungan dengan Perilaku Pemukim di Bantaran Sungai Ciliwung di DKI Jakarta. Tesis tidak diterbitkan. Sekolah Pasca Sarjana. Institut Pertanian Bogor.

Iskandar, Zulriska. 2012. Psikologi Lingkungan: Teori dan Konsep. Bandung: Penerbit Refika Aditama.

Jaya, I.G.N. Mindra., Sumertajaya, IM. 2008. Pemodelan Persamaan Struktural dengan Partial Least Square. Seminar Nasional Matematika dan Pendidikan matematika. UNY. Yogyakarta.

Keraf, A. Sonny. 2010. Etika Lingkungan Hidup. Jakarta: Penerbit Buku Kompas.

Kementerian Negara Lingkungan Hidup. 2013. Perilaku Masyarakat Peduli Lingkungan; Executive Summary. Jakarta.

Leavitt, Harold J. 1978. Psikologi Manajemen. Alih bahasa: Muslichah Zarkasi. Jakarta: Penerbit Erlangga.

Lebreton, L. C. M. et al. 2017. River plastic emissions to the world's oceans. Nat. Commun. 8, 15611 doi: 10.1038/ncomms15611. Diakses pada 3 Desember 2017.

Maryono, Agus. 2015. Pengelolaan Kawasan Sempadan Sungai. Yogyakarta: Gadjah Mada University Press.

Nararya, Sybila. 2017. Apa yang dimaksud Persepsi?. Tersedia di https://www.dictio.id/t/apa-yangdimaksud-dengan-persepsi/4669/2. Diakses pada 21 Desember 2017.

Nugroho, Bagong Setyo. 1999. Pemahaman Masyarakat di Bantaran Sungai Ciliwung tentang Sanitasi Lingkungan (Studi Kasus di Kelurahan Kampung Melayu Jakarta Timur). Thesis tidak diterbitkan. Program Pasca Sarjana Universitas Indonesia. Depok.

Pemerintah Republik Indonesia. 2007. Undang-undang Republik Indonesia Nomor 26 Tahun 2007 tentang Penataan Ruang. Jakarta

------. 2009. Undang-undang Republik Indonesia Nomor 32 Tahun 2009 tentang Perlindungan dan Pengelolaan Lingkungan Hidup. Jakarta

------. 2008. Peraturan Pemerintah Republik Indonesia Nomor 26 Tahun 2008 tentang Rencana Tata Ruang Wilayah Nasional. Jakarta

------. 2012. Peraturan Pemerintah Republik Indonesia Nomor 27 Tahun 2012 tentang ljin Lingkungan. Jakarta 2015. Peraturan Menteri Pekerjaan Umum dan Perumahan Rakyat Republik Indonesia Nomor 28/PRT/M/2015 tentang Penetapan Garis Sempadan Sungai dan Garis Sempadan Danau. Jakarta.

Salmah, Sjarifah. 2010. Penataan Bantaran Sungai Ditinjau dari Aspek Lingkungan. Jakarta: Trans Info Media.

Sudarman. 2010. Meminimalkan Daya Dukung Sampah Terhadap Pemanasan Global. Jurnal Fakultas Teknik Mesin Universitas Negeri Semarang. Profesional, Vol. 8 No. 1, Mei 2010.

Thoha, Miftah. 2001. Perilaku Organisasi Konsep Dasar dan Aplikasinya. Jakarta: PT. Raja Grafindo Persada.

Triyuly, Wienty. 2010. Penerapan Kebijaksanaan Permukiman Ramah Lingkungan Pada Permukiman Informal di Kota Palembang, Studi Kasus: Permukiman Berdikari di Tepian Sungai Musi Palembang. Seminar Nasional, FTSP-ITN Malang, 2010.

Zulkifli, Arif. 2015. Pengelolaan Kota Berkelanjutan. Yogyakarta: Graha Ilmu. 